\title{
IMPLEMENTATION OF LESSON STUDY AS AN INNOVATIVE PROFESSIONAL DEVELOPMENT MODEL AMONG MALAYSIAN SCHOOL TEACHERS
}

\author{
${ }^{1}$ Chiew Chin Mon, ${ }^{2}$ Mohd Hasani Dali, ${ }^{3}$ Lim Chap Sam \\ ${ }^{I}$ Tuanku Bainun Teacher Education Institute \\ ${ }^{2}$ School of Education \& Modern Languages \\ Universiti Utara Malaysia \\ ${ }^{3}$ School of Education, Universiti Sains Malaysia \\ ${ }^{2}$ Corresponding author: hasani@uum.edu.my
}

\begin{abstract}
Purpose - This qualitative study explored the implementation of Lesson Study, a kind of teacher-directed and bottom-up approach of the Japanese model of teacher professional development in the Malaysian education context. It seeks to answer the question of how implementation of lesson study as an innovative professional development model among Malaysian school teachers influences teachers' pedagogical content knowledge, and what school-based factors support or hinder the implementation of lesson study in the Malaysian context.
\end{abstract}

Methodology - The case study method was employed involving two secondary schools in the state of Kedah. Each school set up a lesson study group as a case. Case A had 9 teachers while case B had 8. The participants of both cases engaged themselves in the lesson study process for a period of 12 months. Each lesson study cycle required the participants to collaboratively plan, discuss, teach, observe and reflect on a particular lesson. Due to various constraints, at the end of this study, case A conducted three lesson study cycles while case B conducted only two cycles. Multiple data sources were gathered through in-depth interviews, observations, group discussions and reflections as well as participants' journal writing.

Findings - The analysis of the qualitative data indicated that the lesson study group setting provided an encouraging opportunity 
and venue for the participants to collaborate, discuss and share their teaching knowledge and experiences. Consequently, the participants expressed that their content knowledge and pedagogical content knowledge were enhanced. They became more reflective and keener in promoting active student participation in their lessons.

Significance - This study revealed that the degree of knowledge enhancement was dependent upon each participant's attitude and commitment towards the teaching profession. However, when provided with sufficient supporting factors such as positive support from the school administrators, committed and dedicated group leaders and strong collegiality among the lesson study team, lesson study could be successfully implemented as an effective and innovative mode of teachers' professional learning.

Keywords: Lesson study, reflective practices, teachers' professional development, student participation.

\section{INTRODUCTION}

Based on widely-held beliefs and perceptions that improving teachers will then improve teaching practices, professional development has become one of the main agendas in educational reforms. More importantly, high quality forms of teacher professional development are linked to improving students' achievement (Garet, Porter, Desimore, Birman, \& Yoon, 2001). For this reason, it is important to review and analyze the effectiveness of the professional development programmes being conducted in Malaysia. As Guskey (2000) stated, "Many conventional forms of professional development are seen as too top-down and too isolated from school and classroom realities to have much impact on practice. As a result, hoped-for improvements are seldom realized" (p. 3).

The primary purpose of this study was to explore the feasibility of lesson study for teacher professional development in the Malaysian education context. Reforms in curriculum and educational policies are aimed to overcome deficiencies and weaknesses as well as to prepare the nation to face global challenges in the future. Malaysia, a developing nation, has been revamping and reviewing educational policies to strive for a higher level of educational standard. The 
New Primary School Curriculum (Kurikulum Baru Sekolah Rendah [KBSR]) implemented in 1983, and the Integrated Secondary School Curriculum (Kurikulum Bersepadu Sekolah Menengah [KBSM]) in 1989 are aimed to promote active student participation in learning. This is in tune with the research evidences and recommendations on effective teaching and learning strategies. Subsequently in 1997, the Smart School Project (Projek Sekolah Bestari) was launched to put more emphasis on the application of Information Communication and Technology [ICT] in teachers' pedagogical practices. In 2003, the Ministry of Education [MOE] implemented the policy of using English language to teach science and mathematics and this was aimed to prepare the nation to face global challenges in the future. These reforms showed that MOE has been working tirelessly to uplift the standard of education to a higher level.

One of the major issues addressed in educational reforms is teachers' quality and this is closely related to teacher professional development. To overcome the deficiencies and weaknesses of teachers' teaching, MOE has been conducting various in-service programmes and courses with the aim to improve teachers' teaching knowledge, skills and competency. It is a widely-held perception and belief that this would have an impact on the teachers, and in turn change and enhance their teaching practices. However, this notion is not necessarily true based on reports and research findings. Teachers who attended the 14-week In-service Smart School Teacher Training were only rated average in their smart-teaching practices which emphasized ICT and innovative pedagogical practices (Lee et al., 2000). This was consistent with a report by MOE on the Smart School Pilot Project that highlighted the weaknesses of the teachers in pedagogical aspects (Kementerian Pendidikan Malaysia, 2001). In addition, MOE also provided non-option subject teachers in primary schools to undertake the six-week intensive Conversion course to address the shortage of school teachers. Such ad-hoc programmes actually raised more doubts and concerns because given such a limited time, it would be a tremendous challenge for teachers to acquire sufficient knowledge and pedagogical skills to teach effectively. To conclude, the in-service programmes conducted may not leave the desirable effects on teachers' teaching. Hence, it is vital to devise, formulate and seek an effective approach to in-service programmes that would enhance teachers' teaching. Lack of continuity and support for the teachers in their professional 
development were argued to have not produced an effective change in teachers' teaching (Loucks-Horsley, Stiles, \& Hewson, 1996). Conversely, it was pointed out that a critical component in any educational reform effort is to provide teachers with opportunities and appropriate support for improvement in pedagogical practice (Darling-Hammond \& McLaughlin, 1995; Garet et al., 2001). Hence, it is vital to analyze the situational context and identify the problems that might have influenced the effectiveness of the inservice programmes conducted for teachers in Malaysia.

\section{TEACHER PROFESSIONAL DEVELOPMENT IN MALAYSIA}

The Teacher Education Division of the Ministry of Education (MOE) shouldering the task to coordinate and conduct in-service programmes for the teachers (Ministry of Education, 2001). In the book, Education in Malaysia: A Journey to Excellence (Ministry of Education, 2001), six types of programmes were listed: (a) the Special Degree Programme, (b) One-year Specialist Certificate Course, (c) Professional Development Programme, (d) the Malaysian Trainer Development Programme, (e) Smart School Course, and (f) the Computer Maintenance Course. These in-service programmes were conducted in 27 teacher training institutions in the country. In addition, there were also other short courses and workshops conducted by the Teacher Education Division, the Curriculum Development Centre, state education departments and district education offices of MOE. The main objective was to enhance teachers' professional development as a means to upgrade the teaching profession. For instance, to overcome the critical shortage of mathematics and science teachers in primary schools, in-service teachers were called to attend the six-week intensive Conversion course.

MOE also conducted the Professional Qualification for Head teachers to enhance aspiring teachers' managing skills. To encourage teachers to enhance their knowledge of teaching, non-graduate school teachers were given the opportunity to attain their degrees via "twinning programmes" co-jointly offered by teacher training institutes and universities (Lee, 2002). On a micro scale, teachers were given incentives and grants to conduct action research for their 
own professional development. Beginning 2008, school teachers are required to fulfill the minimum requirement of seven days of in-service training in a year. This reflects the seriousness of MOE to improve teachers' professional development in Malaysia. Lourdusamy and Tan (1992) classified the in-service programmes for teachers into three main types: enrichment programmes, familiarization programmes and specialization programmes. They noted that the familiarization programmes made the bulk of these courses which was mainly to inform and update teachers' knowledge pertaining to the changes in the curriculum or the policies in the education system. For example, when the government decided to implement the policy of teaching science and mathematics in English in the year 2003, teachers were required to attend the two-week in-service programme or ETeMS to improve their language proficiency. With regards to the approach, the multiplier effect concept was mainly adopted to facilitate the in-service programme in Malaysia (UNESCO, 1987). In this strategy, the Curriculum Development Centre conducted courses for a core of key personnel representatives from all the states in the country. These key personnel representatives, in turn conducted similar courses to other key personnel in their respective states. The state education departments then employed these key personnel to conduct courses for the school teachers. This strategy is also known as the cascading approach (Lee, 2002).

Although there was lack of research studies to gauge the effectiveness of the approach, the implementation of the in-service programmes thus far has drawn much criticism. For instance, reports on the massive KBSR in-service training (Hussein, 1990) and the Smart School Courses (Ministry of Education, 2001) exposed the weaknesses of the in-service programmes because they were not effective and adequate for the teachers. Based on the research findings, Lee (2002) deduced that the in-service courses conducted were ineffective because the key personnel were poorly trained and hence the information acquired by the teachers at the lower level was somehow diluted and distorted. Similarly, there were also reports of shortcomings in teacher preparation for the teaching of science and mathematics in English (Noraini et al., 2007). When compared to other countries such as the United Kingdom, Australia and Japan, the typical trend of in-service programme was missing in the Malaysian context: the school-based in-service training. This referred to self-initiated programmes by the schools or groups of 
teachers to improve their teaching practice. This missing trend of professional development is obvious in the Malaysian education system. One probable reason is the bureaucratic education system that employs the top-down approach. It is acknowledged that the education system in Malaysia is highly centralized and bureaucratic (Morris \& Marsh, 1991).

Schools and teachers are bound to follow and adhere to the rules and regulations of the educational policies legislated in the country. Although there might be a few teachers who practised peer coaching or team teaching in the classroom as encouraged by the educational authorities, they were usually done in a fragmented manner. Compared to the practices in other countries such as the lesson study in Japan, these are deemed negligible and insignificant. In fact, there was no sign or indication to date that school-based in-service education will be emphasized and promoted for teacher professional development. Research studies have shown that school-based inservice education (such as the lesson study in Japan) is effective in enhancing and improving teachers' teaching. For this reason, it is timely that the strength of the school-based in-service education be examined in the local context to provide the much needed impact for teacher professional development in Malaysia.

\section{RESEARCH QUESTIONS}

Given these purposes of the study, this research addresses the following research questions:

1. How does lesson study enhance mathematics teachers' pedagogical content knowledge?

2. What are the school-based factors that support or hinder the implementation of lesson study in the Malaysian education context?

\section{TEACHERS' PERCEPTIONS OF PROFESSIONAL DEVELOPMENT}

Professional development of teachers refers to the activities that enhance the professional career growth. In the context of teaching, it is the process and activities that are designed and carried out 
to enhance the professional teaching knowledge, skills and competency of the teachers that in turn, improve the learning of the students (Guskey, 2000). Due to various issues and weaknesses of the professional development programmes to address teaching problems, teachers generally hold a skeptical view and perception. According to Guskey (2000), professional development was perceived as ineffective as it has shown little impact on teachers' teaching. Very often, professional development activities are perceived as irrelevant and unconnected to the realities in the actual classroom (Lieberman, 1995; Ball \& Cohen, 1999; Elmore, 2002). In other words, professional development do not really address the needs of the teachers' teaching (Lieberman \& McLaughlin, 1992). One of the reasons is the conventional approach of professional development that was seen as top-down and the contents were too isolated from the school and classroom realities to have much impact on the teachers' teaching practices (Guskey, 2000). This issue is critical as teachers' perception of professional development may deny any influence or impact, and thus impede the change of teachers' teaching. Darling-Hammond and Ball (1996) contended: A great deal of what teachers encounter as professional development does not consider them as learners, is not designed to help them develop over time, does not focus on the content or students whom they teach, and does not offer opportunities for focused analysis and reflection. Moreover, most professional development is conducted at a distance from the materials and problems of teachers' work (p. 16).

\section{LESSON STUDY FOR TEACHER PROFESSIONAL DEVELOPMENT}

In the "The Teaching Gap", Stigler and Hiebert (1999) summarized four main features of lesson study. They are: (a) lesson study is based on a long-term continuous improvement model, (b) lesson study maintains a constant focus on student learning, (c) lesson study focuses on direct improvement of teaching in context, and (d) lesson study is collaborative. Lesson study is a structured model of teacher professional development that consists of specific steps in the implementation. In the lesson study process, teachers would spend considerable time in lesson planning to best serve their students' learning (Fernandez and Yoshida, 2001). They will discuss and 
share their evidence on students' learning and then, formulate an effective lesson plan that will best facilitate students' learning on a particular topic (Lewis, 2002).

During lesson planning, teachers will find themselves sharing and thinking about their own experiences in the classroom. This encourages the teachers to reflect and consequently, enhance their teaching knowledge (Fernandez \& Yoshida, 2001). Through the discussions and arguments during lesson planning, Lewis and Tsuchida (1998) observed that the conflicting ideas created would provide the opportunity for teachers to reflect and gain new teaching knowledge and ideas. Subsequently, when teachers observe their peer's teaching, it again provides valuable opportunities for the teachers to examine their teaching practices through self-reflection (Fernandez \& Yoshida, 2001; Lewis, 2002). As such, the processes within the lesson study context looks very promising to enhance teacher professional development. When analyzed explicitly, the model of lesson study itself adheres to the principles of effective professional development. It is a school-based in-service programme that requires teachers to work together and collaboratively improve their teaching practices (Hiebert et al., 2002). Lewis (2002) noted that lesson study would create a learning environment for teachers to collaborate in school. This view was well supported by Shimahara (1998) who expressed that peer collaboration is vital to support the learning the craft of teaching. Nevertheless, Shimahara (1998) cautioned that lesson study would have a minor setback if it is only confined within the peer group in the school. Having reviewed briefly the structure and processes of lesson study, it seems clear that lesson study is consistent to the principles of effective professional development. More importantly, lesson study is structured as a longterm programme for teacher professional development that has been practised since decades ago in Japan.

To support the basis of this study, it is imperative to review some of the research evidence pertaining to lesson study. Although the idea of lesson study originated in Japan, ironically the bulk of research documented was from the United States. Based on the literature, the book entitled The Teaching Gap: Best Ideas from the World's Teachers for Improving Education in the Classroom by Stigler and Hiebert (1999) had made lesson study gain much attention in the United States. One of the first groups of teachers engaging in 
lesson study was from an elementary school in New Jersey. In 1997, Lynn Liptak, the principal and 16 teachers of Paterson School No. 2 of New Jersey attended a workshop and viewed the videotapes (from TIMSS) of mathematics teaching being taught in the United States and Japan. They were impressed with the Japanese-style mathematics lesson and also learned that lesson study is a form of teacher professional development in Japan. In 1999, the group sought help from Clea Fernandez and Makoto Yoshida who were lesson study researchers. In February 2000, the Paterson School No. 2 hosted the first lesson study open house in the United States. The lesson was planned by four teachers and taught to 19 second graders about multiplication problems. Although Lewis (2002) expressed that it was premature to evaluate the impact of lesson study, WangIverson (2002) reported the positive effects of lesson study on the teachers and it has then become a vital part of teachers' professional growth in Paterson School No. 2.

In 2000, four mathematics teachers from the San-Mateo Foster City School in California became aware of lesson study after attending a workshop that focused on the TIMSS video study (Perry, Lewis \& Akiba, 2002). Subsequently, they formed a study group to develop mathematics lessons and were introduced to the lesson study by Patsy Wang-Iverson and Catherine Lewis. Through their initiatives and support from the district administration, they recruited 28 teachers from different schools to participate in lesson study. They sought the help of Catherine Lewis and Rebecca Perry from Mills College as researchers to document their research effort. The findings revealed that the lesson study activities help the teachers to develop the subject matter and enhance their pedagogical knowledge that is similar to the goals of teacher professional development (Perry, Lewis \& Akiba, 2002). Lesson study at the San-Mateo Foster City School continued to grow and after three years of inception, the number of participating teachers increased to 78 .

In another research, Lewis, Perry and Murata (2003) studied three lesson study groups separately to examine the relationship between lesson study and development of teachers' knowledge. The first group consisted of 5 Grade Three teachers focusing on number sense and problem solving. The data gathered revealed the enhancement of teachers' thinking with regards to students' learning 
difficulties. The second group consisted of 3 kindergarten teachers using concrete objects as manipulatives for problems involving addition and subtraction. They found it challenging to predict students' questions and responses. The third group of participants consisted of 6 elementary teachers focusing on patterns for algebraic thinking. Evidence suggested that teachers develop the knowledge of understanding students' learning difficulties. These research evidence portrayed that lesson study is indeed an effective model for teacher professional development.

Research studies to date have been supporting the practices of lesson study for teachers' professional development (Lewis \& Tsuchida, 1998; Stigler \& Hiebert, 1999; Fernandez \& Yoshida, 2001; Lewis, 2002; Hiebert et al., 2002). Nevertheless, Lewis (2002) cautioned that lesson study is successful in Japan due to its various supporting conditions in the country. Although she has an optimistic view with regards to lesson study, she foresees that lesson study may need to be reviewed and re-structured to suit the context in Malaysia.

\section{METHODOLOGY}

Qualitative research is known to be able to provide a rich and deep understanding of social phenomena compared to quantitative research (Silverman, 2005). The case study design was chosen for this study as Creswell (1998) defined case study as "an exploration of a bounded system or a case (or multiple cases) over time through detailed, in-depth data collection involving multiple sources of information rich in context" (p. 61). However, due to constraints in time and resources, this study focused on only two cases. This was also to allow the researcher to investigate each case deeply. The two cases comprised of 17 teachers serving in two secondary schools and they were nominated by their respective school administrators who gave the consent for the research to be conducted.

The lesson study process adopted in this study was a kind of teacher professional development originated from Japan. To evaluate teacher professional development, Guskey (2000) proposed five yardsticks: (a) participants' reaction, (b) participants' learning, (c) organization support and change, (d) participants' use of new knowledge and skills, and (e) student learning outcomes. Having 
selected qualitative case study as the research design, two groups of secondary school mathematics teachers were sought as participants. School A and School B (both pseudonyms), located within the district of Jitra in Kedah were chosen mainly because the sites were near the researcher's premises. However, the more important consideration in selecting both the schools was the school principals' consent and permission to carry out the research. This aspect is deemed vital to carry out any research study in Malaysia. No specific criteria were imposed by the researcher in selecting the schools as the initial and real concern was getting the consent of the school principals as "gate-keeper."

\section{DATA COLLECTION}

This study employed multiple techniques of data collection: interviews, observations and transcripts of the lesson study discussions and teaching. Interview is the most widely employed method to collect data in qualitative research (Bryman, 2004). Through interviews, the researcher can obtain rich, in-depth and detailed information that shows or reflects the views and perceptions of the participants. Interviews are also appropriate to seek information in the past as concurred by Merriam (1998) that, "It is also necessary to interview when we are interested in the past events that are impossible to replicate" (p. 72).

Table 1

Number of Lesson Study Discussions

\begin{tabular}{ccc}
\hline Site & Lesson study cycle & Number of discussions \\
\hline School A & First & 3 \\
& Second & 3 \\
\multirow{3}{*}{ School B } & Third & 3 \\
& First & 3 \\
& Second & 5 \\
\hline
\end{tabular}

Table 1 shows the number of lesson study discussions conducted for each cycle prior to the first teaching. This includes the discussion of the contents and problems often faced by the participants in teaching the content of the lesson. 
Hence, data pertaining to the participants' teaching practices prior to their engagement in lesson study were sought via interviews with the participants. The researcher used semi-structured interviews as suggested by Yin (1994) and Creswell (2003) to focus on certain aspects of interest that were relevant to and important for this study. However, unstructured parts of the interviews were also allowed to collect any unanticipated data that were deemed vital and relevant to conceptualize the findings of this study. There were two forms of interview in this study: individual interview and group interview that were conducted at the end of every lesson study cycle. Prior to the participants' engagements in lesson study, individual interviews were conducted to conceptualize their mathematics teaching practices in the schools. Since individual interview was conducted with the participants after each cycle, the researcher was able to note and gauge any changes in the participants. Through these interviews, any change in the participants' attitudes and perceptions over a one-year period could be determined. The number of individual interviews conducted with each of the participants is shown in Table 2 and Table 3.

Table 2

Individual Interview Conducted with Participants of School S

\begin{tabular}{cccccc}
\hline & 1st cycle & 2nd cycle & 3rd cycle & Total & Note $(\mathrm{X})$ \\
\hline Rohani & $\sqrt{ }$ & $\sqrt{ }$ & $\sqrt{ }$ & 3 & Maternity leave \\
Zaiton & $\mathrm{X}$ & $\sqrt{ }$ & $\sqrt{ }$ & 2 & \\
Jayanthi & $\sqrt{ }$ & $\sqrt{ }$ & $\sqrt{ }$ & 3 & \\
Aishah & $\sqrt{ }$ & $\sqrt{ }$ & $\sqrt{ }$ & 3 & \\
Maria & $\sqrt{ }$ & $\sqrt{ }$ & $\sqrt{ }$ & 3 & \\
Nori & $\sqrt{ }$ & $\sqrt{ }$ & $\mathrm{X}$ & 2 & Maternity leave \\
Raja & $\sqrt{ }$ & $\sqrt{ }$ & $\sqrt{ }$ & 3 & \\
Suraya & $\sqrt{ }$ & $\sqrt{ }$ & $\mathrm{X}$ & 2 & \\
Malik & $\mathrm{X}$ & $\mathrm{X}$ & $\sqrt{ }$ & 1 & \\
\hline
\end{tabular}

At the end of each lesson study cycle, four group interviews were conducted with the participants to gain an overview of the lesson study process conducted. All group interviews were videotaped and later transcribed by the researcher. After each lesson study cycle was completed, the researcher conducted an interview with each participant. The duration for each interview was between 20 
to 50 minutes with an average of 25 minutes. The participants were interviewed individually with semi-structured and open-ended questions to probe the participants' views and reflections of the lesson study conducted.

Table 3

Individual Interview Conducted with Participants of School K

\begin{tabular}{ccccc}
\hline & 1st cycle & 2nd cycle & Total & Note $(\mathrm{X})$ \\
\hline Ziti & $\sqrt{ }$ & $\sqrt{ }$ & 2 & \\
Hafizah & $\mathrm{X}$ & $\sqrt{ }$ & 1 & \\
Rohana & $\mathrm{X}$ & $\sqrt{ }$ & 1 & Rarely participated \\
Salwa & $\mathrm{X}$ & $\sqrt{ }$ & 1 & Withdrew \\
Jaafar & $\sqrt{ }$ & $\mathrm{X}$ & 1 & Withdrew \\
Lee & $\sqrt{ }$ & $\mathrm{X}$ & 1 & Withdrew \\
Rosli & $\sqrt{ }$ & $\mathrm{X}$ & 1 & Withdrew \\
Teoh & $\sqrt{ }$ & $\sqrt{ }$ & 2 & \\
\hline
\end{tabular}

Besides the participants, individual interviews were also conducted with the Principal and the Senior Assistant (1) of School A at the end of this study as supplementary data. Since the school administrators were not directly involved and their roles were not clearly defined in this study; however their support and concern seemed to have weighted and influenced the lesson study outcomes. In principle, the school administrators were supportive of the lesson study as they had granted their consent for the research. Besides the interviews, direct observations by the researcher throughout this study were another prime source of data. Since the researcher is a primary instrument in qualitative research, observation is imperative to provide first-hand information and credible data of the events and participants (Merriam, 1998; Creswell, 2003). Moreover, Creswell (2003) stressed that any unusual situations or aspects of the research context could also be noted through observations. These include nonverbal signs and gestures of the participants during the lesson study sessions and these could be documented via the researcher's field notes. For this study, the researcher played dual roles: participant observer and complete observer. Ideally, the researcher sought the role of complete observer to reduce bias and threats that could upset the natural setting. 


\section{DATA ANALYSIS}

A distinctive characteristic of qualitative research is the on-going analysis during the process of data collection (Neuman, 2003). Hence, there were two stages of data analysis in this study: data analysis during fieldwork and post-fieldwork data analysis. The data analysis during fieldwork was vital to enable the researcher to focus and conceptualize key emerging issues, in particular the constraints and challenges of implementing lesson study. Consequently, to move on with this study, the researcher allowed some flexibility to overcome the challenges faced in the lesson study implementation. At the preliminary stage of this study, the researcher performed the role of lesson study facilitator to engage the participants. This was to ensure that the participants were appropriately engaged as in the actual context of lesson study. Due to the constraints faced in the lesson study implementation, preliminary analysis allowed the researcher to reflect and wonder if the constraints were due to the educational system and the teaching culture which was further examined after the data collection was completed.

Another issue encountered during fieldwork was the attitude and commitment of the participants. There were signs and gestures of reluctance among the participants to engage in the lesson study at the beginning but they began to show interest as the research progressed. For instance, they deliberately showed little interest in sharing and discussing during the discussion sessions. Preliminary analysis helped the researcher to determine if the participants were coerced into participation by their school administrators or they had yet to understand and conceptualize the rationale of lesson study. The findings that emerged included the participants' attitude and the lack of awareness of teacher professional development in the schools as one of the key factors uncovered was the reluctance of the participants to stay back after school. Nevertheless, the major data analysis work was conducted upon the completion of the fieldwork.

All group discussions, interviews and teaching that were either audio-taped or video-taped were transcribed into verbatim transcripts. The post-fieldwork data analysis involved analyzing the data from field notes, interview transcripts of the discussions 
and teachings. These data, collected over the 12-month period, were indeed voluminous and the research questions provided great assistance to the researcher in analyzing the data as suggested by Miles and Huberman (1994).

Having scrutinized and analyzed the data, the researcher decided to elaborate and discuss separately the events of the lesson study cycles at the two sites. The key issue was the differences in the research context; the environment, contextual factors and participants of School A and School B differed from one another and these influenced the outcomes of the lesson study. Although there are considerable variations in the ways data are analyzed, this study used the five steps of data analysis and they were mainly on suggestions from Miles and Huberman (1994) with support from other sources (such as Merriam, 1998; Richards, 2005; Neuman, 2006). The initial step taken to analyze the data was the identification of key ideas. Based on the transcribed data, and field notes, the researcher read several times and synthesized the information to get a general sense or idea that reflects the whole study as suggested by Creswell (2003). In reality, each transcript was read until its meanings that reflect the ideas in the paragraph were clear. Although qualitative research paradigm stresses the findings to surface from empirical data (Richards, 2005), the researcher focused on data related to the research questions that were identified and gathered as codes. This was mainly due to the voluminous data collected. In addition, interviews were conducted with participants for every lesson study cycle conducted and thus, many phrases, key ideas and words quoted were repeats or resembled similar meanings. For instance, some quotes from the data such as "change of the teaching", "the lesson is different from what we are doing" and "last time was teachercentered, now student-centered" were identified and gathered as codes. In this step, the researcher extracted relevant and appropriate quotes or words from each transcript and placed them under major themes of the research questions. In the course of this action, some data were probably neglected if deemed irrelevant in the view of the researcher. Bogdan and Biklen (1998) statues that, "Analysis involves working with data, organizing them, breaking them into manageable units, synthesizing them, searching for patterns, discovering what is important and what is to be learned, and deciding what you will tell others" (p. 157). 
As the quotes relevant to each theme were extracted, initial domains began to emerge from the data. The quotes were then re-examined whether they appropriately fitted the domain while new ones were created to cater to the needs. In the same domain, data retrieved from the researcher's field notes had the following: participants' attitude towards work and teaching profession, school cultural factors and teachers' awareness of professional development. Besides the responses gained from the participants, the events in each of the lesson study cycle also provided the data and evidence. The next task was to refine these domains and cross-check if they were deemed appropriate. In reality, many of the domains were interrelated and could not be clearly distinguished. Besides, data from the two sites were compared, analyzed and contrasted to enhance their reliability. The cross-case analysis allowed the researcher to identify and conceptualize the emerging themes from the study which were guided by the research questions. At the same time, analysis was also made for any contradicting evidence in the study. As this study was qualitative, and therefore interpretative in nature, the researcher concluded the overall findings on personal views and reflections guided by the principles in qualitative research. This was expressed by Creswell (2008), "Because you may have been to the field and visited personally at great length with individuals, you are in a good position to reflect and remark on the larger meaning of the data" (p. 265). Nevertheless, the findings were also compared and contrasted with the literature and past studies to establish the worth of this study. In doing so, the researcher disclosed the weaknesses and limitations of this study to help readers to interpret and deduce the concluded findings.

\section{CREDIBILITY AND TRUSTWORTHINESS OF DATA}

Neuman (2003) and Silverman (2005) stressed and highlighted the importance of validity and reliability in qualitative research. In Naturalistic Inquiry, Lincoln and Guba (1985) used the term "trustworthiness" to cover credibility, transferability, dependability and conformability for the validity and reliability of qualitative data. Creswell (2008) pointed out that the background of the researcher has some influence and significance on the findings deduced. For this reason, various measures were undertaken to reduce such threats as credibility and trustworthiness of the data were of utmost 
importance in research. Hence, the following steps were undertaken by the researcher: familiarity with the sites, long-term observation, member check and triangulation of methods and data.

Qualitative research using the interpretative approach depends largely upon the researcher to provide truthful information about the data collected. As a participant observer, the researcher immersed himself in the research context and hence, was able to construct closely the views and perspectives of the participants in the lesson study process. As the researcher was new to the sites, he made efforts to visit the schools as frequently as possible to establish good rapport and buil mutual thrust and understanding with the participants. The mutual understanding established was vital to boost the credibility of the data. Lincoln and Guba (1985) revealed that prolonged engagement would enable the researcher to build mutual trust with the participants and learn the culture in the context. The period of 12 months allotted for data collection was deemed sufficient for the researcher to understand the research context well and this helped to provide credibility to the narrative account of the researcher (Merriam, 1998; Creswell, 2003). It is imperative that the researcher provides rich and detailed description of the study to enable readers to transfer information to other settings (Lincoln \& Guba, 1985; Creswell, 2003). For this reason, the researcher needed to be persistent in his observation throughout the data collection.

Merriam (1998) refers to member check as, "taking data and tentative interpretations back to the people from whom they were derived and asking them if the results are plausible." (p. 204). After the interviews were transcribed into textual forms by the researcher, the transcriptions were validated with the participants. This step allowed the researcher to seek clarity with the participants and verify whether the researcher's construction of the findings resembled the views of the participants. This step was undertaken to enhance the credibility of the data collected. Triangulation is vastly employed in qualitative research data analysis to enhance the trustworthiness of the data (Lincoln \& Guba, 1985). Hence, this study employed two techniques of triangulation: methods and data. Triangulation of data refers to the data collected from different informants or sources to support the findings deduced. Data were triangulated from interviews with multiple participants. Triangulation of data stretched beyond multiple sources of data collection: interviews with the participants 
and field notes of the lesson study process at various stages. This step was undertaken by the researcher to ensure that the process of inquiry was logical and well documented in enhancing the credibility and trustworthiness of the data.

\section{RESULT AND DISCUSSION}

Through data analysis, emerging themes were identified and these included: (a) enhanced teachers' content knowledge, (b) improved teachers' pedagogical content knowledge, (c) developed teachers' pedagogical knowledge, (d) promoted teachers' reflective practice, (e) developed teachers' collegial relationship, (f) emphasized active student participation in teaching, $(\mathrm{g})$ encouraged the practice of lesson planning, and (h) developed motivation for self-development.

\section{Enhanced Teachers' Content Knowledge}

The lesson study cycles conducted on various topics have indeed enhanced the participating teachers' content knowledge. However, the contents gained by each individual depended much upon the topic of the lesson discussed as well as the participants' backgrounds, attitudes and commitment towards the lesson study. For instance, Raja who lacked mathematics content knowledge was seen struggling to keep up with the discussions about rotation. Although he was confused at the beginning, Raja revealed that he had gained much content knowledge of rotation through the lesson study discussions. Raja elaborated:

For me, when we discuss and choose the topic together, we then chose the topic of rotation. When I heard about rotation for the first time, I actually don't understand it. For me, the topic is quite blur because when I studied it last time, the way I learnt was different. Later, when we discuss and when a few of the teachers gave some idea, then only I understood about rotation. (Interview 26a: 03/11/13)

The influence on Raja's content knowledge was probably much more than the other participants as his subject specialization was not Mathematics. During the lesson study discussions, the participants 
shared their teaching knowledge and through their self-reflection, they naturally gained more content knowledge. As reflected by Maria:

I think OK, actually it's [lesson study] good. . . can enhance our knowledge. We have been thinking our knowledge is adequate but when we discussed, we feel there are more things that we don't know. I feel that way because many heads are better than one head. (Interview 20b: 26/10/13)

Similarly, Ziti reflected that her content knowledge was inadequate and this implied that she actually gained some content knowledge through the lesson study process. She said:

So far when we teach any topics, we assume that we got the best way. We assume our students can understand it. Actually, when we discuss, there are so many shortcomings. Sometimes, we are also not comfortable with our content knowledge. We do not know a lot of things. (Interview 29b: 27/04/14)

\section{Enhanced Teachers' Pedagogical Content Knowledge}

Besides the content knowledge, the participants acknowledged that the lesson study process had also enhanced their pedagogical content knowledge in a similar way: lesson planning, teaching observation and reflection on teaching. In fact, the influence on their pedagogical content knowledge was far more significant compared to content knowledge in every lesson study cycle.

Prior to the lesson study, the participants employed other teaching approaches; number line for addition of integers and counting grids for rotation. Suraya reflected the benefits gained through lesson study.

"Benefits ... ideas from friends ... then, more confident of the mathematics concepts. As we have done, the chips... that's new idea to me".

(Interview 14a: 11/08/13)

At the end of this study, the participants claimed that they have acquired new teaching ideas and approaches via the lesson study process. As Aishah said, "Mm ... I think it did enhance our knowledge 
like the use of chips. Prior to this, as I had said previously, we know (about the chips) but we have not tried it because we don't know how to use it" (Interview 16b: 12/08/13)

Following the positive outcomes of the lesson study cycle at School A, the participants continued to seek effective teaching approaches. The participants expressed satisfaction when they saw that their teaching strategies enabled the students to grasp the mathematics contents and concepts more easily. Evidently, the participants had developed their pedagogical content knowledge in varying degrees. In most cases, the teaching became easier after the participants had discussed and planned the lesson systematically. Suraya reflected that the lesson on rotation was much easier than before and she attributed it to the influence of lesson study that enhanced her pedagogical content knowledge:

\section{Developed Teachers' Pedagogical Knowledge}

The lesson plans developed through the lesson study discussions incorporated various teaching strategies and this had developed the participants' pedagogical knowledge. At School B for instance, the participants were quite impressed with the cooperative learning strategy in the lesson study cycle. The participants were excited and Hafizah acknowledged that the lesson study process had developed her pedagogical knowledge:

Mm . . yes, especially how to start a lesson . . . like thinking of examples why you must learn factorization and class activities... the cooperative learning. I think it can be used even though not for all the topics. Sometimes we can change the way so that the students will not get bored. This is the first time I had conducted cooperative learning. I never... never do this before. (Interview 22b: 28/10/13)

To conclude, the participants were motivated to attempt the cooperative learning strategy based on their observations of the positive teaching outcomes. Lesson study had provided the opportunity for the participants to plan effective teaching strategies and conduct the lessons in a systematic manner, and this to a certain extent had developed their pedagogical knowledge. 


\section{Promoted Teachers' Reflective Practice}

The enhancement of teachers' reflective practice is actually due to the nature and the structured model of lesson study. It is deduced that lesson study is merely providing the opportunity and venue for the participants to meet and discuss matters pertaining to their teaching practices and indirectly, has promoted their reflective practice. Hafizah disclosed her enhancement of reflective practice:

Yes . . because we want to make sure the lesson plan is good and well-planned, so we try to think together. Sometimes we just talk how to do this and maybe our friends also explain how he/she do it ... so we can get sort of one conclusion. (Interview: 27/04/14)

In addition, the enhancement of reflective practice was also uncovered through peers' lesson observations. Jayanthi said in an interview on 10 August, 2013.

I just took it for granted that this is so simple and clear that they should understand. When I observed the teacher, then only I know what is actually going wrong. We cannot see that when we are teaching because we cannot observe ourselves.

Reflective practice has been regarded as the fundamental process to support a teacher's change in teaching practice (Schon, 1987; Ball, 1996). The lesson study has indeed influenced teachers' reflective practice and this provided some incremental change to the teachers' teaching practice.

\section{Developed Teachers' Collegial Relationship}

Although the participants were struggling for time to participate in the lesson study, they revealed that they actually had enjoyed the experience with their peers. The feel good atmosphere as expressed by some of the participants reflected that they were generally happy to work together with their peers if given the chance and opportunity in school. This consequently had enhanced their collegial relationship. As Ziti said, "About 80\% I think I enjoyed 20\% [not happy] because of the time. Too tired to think about it” (Interview: 27/04/14). Teoh 
echoed a similar sentiment, "Ah! I quite enjoy it because when you discuss, you really learn a lot of things. I don't know about others but personally, I enjoyed it”. (Interview: 27/04/14)

In summary, the participants appreciated and valued the opportunity to collaborate with their peers via the lesson study process and this had broken the barrier of teachers' isolation. Indirectly, lesson study is able to develop collegial relationship as documented in the literature and this was also concurred by Lewis (2005).

\section{Emphasized Active Student Participation in Teaching}

Although lesson study is not intended to promote active student participation in teaching, the lesson plans developed by the participants inclined to engage the students actively with handson or group work activities. Ziti reflected about the change in teachers' teaching, "Last time was teacher-centered this time was student-centered in the teaching" (Interview 20c: 27/10/13). This suggested a change in teachers' teaching as prior to the lesson study, the participants generally adopted the teacher-centered teaching approach. Having participated in the lesson study cycle, Teoh gained a positive perception of the cooperative learning strategy that had engaged the students actively in learning. He elaborated, "I asked them [students] for their opinion about the teaching. They said it was very enjoyable and they hope I can continue doing it . . . meaning something different in the lesson" (Interview: 27/04/14). These remarks suggest that the participants were glad with the lesson study outcomes; the planned lessons had engaged the students actively in learning. Previously, these had been shunned in their teaching routines. From the analysis, it was deduced that the lesson study was able to promote active student participation in learning as envisioned in the Malaysian curriculum. This was similar to a report by Wang-Iverson (2002) that lesson study has influenced teachers to believe that lessons should be student-centered instead of teachercentered.

\section{Encouraged the Practice of Lesson Planning}

One of the principles of effective teaching is good planning of the lesson plan (NCTM, 1989). The participants were generally pleased with the lesson study outcomes as it was able to cultivate and promote 
the awareness of lesson planning. They expressed disappointment with the teachers who have not been putting sufficient time and effort in lesson planning. Fauzi lamented, "The trend nowadays, most of the teachers when they enter the class, then only they think and plan the teaching, and learning and others" (Interview 34b: 17/05/14). Rohani agreed with Fauzi, "We used to teach lessons without proper planning ... this [lesson study] benefits the teachers a lot especially preparing of the lesson because we need to discuss the lesson". (Interview: 17/05/14).

Most of the participating teachers seemed aware the importance of lesson planning but due to the constraints in the school such as teacher's workload, very little time is indeed spent on lesson planning. During lesson study discussions, the participants discussed the lesson plan in detail and the support from the participating teachers could indeed promote the awareness of lesson planning.

\section{Developed Motivation for Self-development}

At least two participants, Jayanthi and Hafizah, were motivated for self-development in teaching after engaging in the lesson study process. The influence of lesson study to both the participants was rather similar; they realised their weaknesses and the shortcomings of their knowledge in teaching through self-reflection which in turn influenced their attitudes and commitment towards lesson study. Gradually, they became more positive and receptive towards lesson study. Ziti exposed that Hafizah was keen on lesson study, "Hafizah ... she is willing to learn, she can sacrifice her time. She regards herself new and she wants to learn" (Interview 29c: 27/10/13). Jayanthi related her personal experience that made her attracted to lesson study: Actually for me, everything is quite new because I have just started teaching. I have never heard about it. They [lecturers] never give us any clue when we were in the teacher training college. No books, nobody suggested anything . . . even the constructivism, they didn't explain to us properly. I didn't understand the concept until I join this lesson study (Interview: 18/05/14).

Compared to other participants in this study, Jayanthi and Hafizah showed much enthusiasm to engage in lesson study as they realized the benefits of the lesson study in enhancing their teaching. They were motivated through their self-reflection which in turn encouraged 
them to participate actively. To conclude, the lesson study process seems able to motivate teachers to seek self-improvement as it actually creates an opportunity and provide room within the school context to support teachers' learning. Hence, strong desire and the willingness of the teachers to seek professional development would be a prerequisite because the lesson study is merely providing the opportunity and venue for the teachers which in fact, is severely lacking in the Malaysian school context. Lesson study is self-directed and therefore, it would depend much on the teachers' initiatives to seek changes in their teaching.

The emerging themes as discussed have unveiled the influence of the lesson study in this research. Despite the differences in the education system and teaching culture, the influences are in many ways, similar to the findings as reported in related lesson study research from abroad such as in Japan and the United States. Even though there are constraints and challenges in this study, the overall outcomes were positive and encouraging in the context of teachers' learning and professional development. The participating teachers expressed confidence that the practice of lesson study in the longterm could influence or perhaps, change their teaching practice. They are optimistic that the lesson study will indirectly influence the teachers' teaching but stressed that most of the practising teachers in Malaysia are yet to be prepared to engage in lesson study for teacher professional development. Although they acknowledged the relevance of lesson study in the context of teacher professional development, they were skeptical of lesson study implementation in the Malaysian schools.

\section{CONCLUSION}

The findings of this study propose that lesson study could be an innovative model of professional development that is effective in enhancing teachers' pedagogical content knowledge through peer collaboration. As stated by Garet et al. (2001) teachers who gained content knowledge and teaching skills from teacher professional development programmes are more likely to change their teaching practice in the classroom. Murata, Lewis and Perry (2004) explained that the increased knowledge-base of teachers through lesson study 
is only the intermediate outcome that would in due course be translated to improved classroom teaching as the long-term outcome. On a similar note, Lewis (2005) identified seven key pathways that connect lesson study to improved classroom instruction and two of the key pathways are increased knowledge of subject matter and increased knowledge of instruction.

The significance of content and pedagogical content knowledge as knowledge-base for teaching has been widely recognized by educators (such as Shulman, 1986; Ball, 2000; Dudley, 2014) and Ball (2000) contended that acquiring such knowledge evolved naturally through one's interaction and experience. Prior to the introduction of lesson study, the participating teachers were working in isolation as there were no structural activities of professional development in the school in which they could collaborate and work together with one another. Lesson study provides the context and venue for the teachers to enhance their pedagogical content knowledge as they engage in active discussion and self-reflection. In fact, the nature of the lesson study process provides an opportunity for teachers to reflect and this influences their reflective skills. Besides peer support, the researcher who acted as lesson study facilitator also scaffolded the participating teachers to greater height as propagated by Vygotsky (1978). The lesson study cycles improved the participants' pedagogical content as they shared and discussed among themselves which also promoted them to be more reflective. Such an environment and circumstances are critically important for teachers' learning (Ball, 2001).

Findings of this study imply that lesson study could provide an alternative and innovative model for teacher professional development in Malaysia. Lesson study has been proclaimed as an effective model of professional development in the literature (such as Stigler \& Hiebert, 1999; Lewis, 2002; Fernandez \& Yoshida, 2004) and therefore, it has the potential to influence teachers' teaching as reflected from the findings and results of this study. However, lesson study is teacher-directed and resembles a bottom-up approach of professional development (Lewis, 2002) that demands much time and commitment from the teachers such as a positive attitude towards the teaching profession. As evidenced from the findings of this study, the implementation of lesson study at School A and School B was constrained by several factors, namely time teachers' 
workload and the exam-oriented culture which are inter-related with one another. The interplay of these factors has restricted the smooth accomplishment of the lesson study process. Indirectly, these restricting factors reflected two major implications: (a) there is a lack of teachers' awareness towards professional development, and (b) a strong emphasis of exam-oriented culture in the Malaysian education context.

To conclude, it is a worthy agenda to promote lesson study as an innovative school-based teacher professional development in the long-term. The school administrators have a prominent role to support and motivate the teachers to strive for their professional development. The teacher educators or master teachers could extend their teaching expertise as knowledgeable others by working and collaborating with the practising teachers in schools. This builds a network of teacher collaboration and cooperation that is highly recommended in the context of teacher learning. For this reason, the lesson study model may serve as a promising and innovative approach to improve teaching as elaborated by Cerbin and Kopp (2006). The lesson study, if implemented in the Malaysian education context, would mark a major paradigm shift for teacher professional development.

\section{REFERENCES}

Ball, D. L. (2001). Studying practice to learn in and from experience. Invited keynote address to the California Mathematics Council Annual meeting, Asilomar, November 30, 2001.

Ball, D. L., \& Cohen, D. K. (1999). Developing practice, developing practitioners: Toward a practice-based theory of professional education. In L. Darling-Hammond \& G. Sykes (Eds.), Teaching as the learning profession: Handbook of policy and practice (pp. 3-32). San Francisco: Jossey-Bass Publishers.

Bogdan, R. C., \& Biklen, S.K. (1998). Qualitative research for education. Boston: Allyn and Bacon.

Bryman, A. (2004). Social research methods. New York: Oxford University Press.

Cerbin, W., \& Kopp, B. (2006). Lesson study as a model for building pedagogical knowledge and improving teaching. International Journal of Teaching and Learning in Higher Education, 18(3), 250-257. 
Creswell, J. W. (1998). Qualitative inquiry and research design: Choosing among five traditions. Thousand Oaks: Sage Publications.

Creswell, J. W. (2003). Research design: Qualitative, quantitative, and mixed methods approaches. United States: SAGE Publications.

Creswell, J. W. (2008). Educational research: Planning, conducting, and evaluating quantitative and qualitative research. New Jersey: Pearson Education International.

Darling-Hammond, L., \& McLaughlin, M. W. (1995). Policies that support professional development in an era of reform. Phi Delta Kappan, 76(8), 597-604.

Elmore, R. F. (2002). Bridging the gap between standards and achievement: The imperative for professional development in education. Washington, D.C.: Albert Shanker Institute. Available at http//www.ashankerinst.org/Downloads/Bridging Gap.pdf_

Fernandez, C., \& Yoshida, M. (2001). Lesson study as a model for improving teaching: Insights, challenges and a vision for the future. Eye of the Storm: Promising Practices for Improving Instruction. Retrieved from http://www.c-b-e.org/PDF/ EyeoftheStormFernandez.pdf

Garet, M. S., Porter, A. C., Desimore, L., Birman, B. F., \& Yoon, K. S. (2001). What makes professional development effective? Results from a national sample of teachers. American Educational Research Journal, 38(4), 915-945.

Guskey, T. R. (2000). Evaluating professional development. Thousand Oaks: Corwin Press.

Hiebert, J., Gallimore, R., \& Stigler, J. W. (2002). A knowledge base for the teaching profession: What would it look like and how can we get one? Educational Researcher, 31(5), 3-15.

Hussein Ahmad. (1990). Keberkesanan penyediaan guru dan aktiviti meningkatkan profesionalisme mereka. Seminar Kebangsaan Penilaian Pelaksanaan KBSR. Pusat Perkembangan Kurikulum, Kementerian Pendidikan Malaysia, 35-56.

Kementerian Pendidikan Malaysia. (2001). Laporan pemantauan kolaboratif pelaksanaan projek rintis sekolah bestari. Kuala Lumpur: Bahagian Sekolah, Kementerian Pendidikan Malaysia.

Lee, M. N. N. (2002). Teacher education in Malaysia: Current issues and future prospects. In E. Thomas (Ed.), Teacher education: Dilemmas and prospects (pp. 57-68). London: Routledge. 
Lee, L. G., Abd. Shukur A. Shaghir, Ahmad Nasir Muhamad, Faharol Razi Shaari, \& Ku Bahaudin Ku Hashim. (2000). Pengendalian pengajaran pembelajaran bestari di sekolah bestari perintis. In Indra Devi S., \& Ng, C.M. (Eds.), Prosiding Seminar Kebangsaan Penyelidikan dan Pembangunan dalam Pendidikan: Penyelidikan ke arah Inovasi dalam Pedagogi (hlm 85). Bahagian Pendidikan Guru, Kementerian Pendidikan Malaysia.

Lewis, C., \& Tsuchida, I. (1998). A lesson is like a swiftly flowing river: Research lessons and the improvement of Japanese education. American Educator, 14-17 \& 50-52.

Lewis, C. (2002). Does lesson study have a future in the United States. Nagoya Journal of Education and Human Development, (1), $1-23$.

Lieberman, A. (1995). Practices that support teacher development. Phi Delta Kappan, 76(8), 591-596.

Lieberman, A., \& McLaughlin, M. W. (1992). Networks for educational change: Powerful and problematic. Phi Delta Kappan, 73(9), 673-677.

Loucks-Horsley, S., Stiles, K., \& Hewson, P. (1996). Principles of effective professional development for mathematics and science education: A synthesis of standards. National Institute for Science Education Brief, 1(1). Madison: University of Wisconsin-Madison.

Lourdusamy, A., \& Tan, S. K. (1992). Malaysia. In H.B. Leavitt (Ed.), Issues and problems in teacher education: An international handbook (pp. 179-191). New York: Greenwood Press.

Merriam, S. B. (1998). Qualitative research and case study applications in education. San Francisco: Jossey-Bass Publishers.

Miles, M. B., \& Huberman, A. M. (1994). Qualitative data analysis. Thousand Oaks: Sage Publications.

Ministry of Education. (2001). Teacher education. Education in Malaysia: A journey to excellence (pp. 87-105). Ministry of Education.

Morris, P., \& Marsh, C. (1991). Patterns and dilemmas. In. C. Marsh \& P. Morris (Eds.), Curriculum development in East Asia (pp. 255-271). London: The Falmer Press.

Murata, A., Lewis, C., \& Perry, R. (2004). Teacher learning in lesson study: Developing professional capacity and resources. Paper presented at the North American Chapter of 
the International Group for the Psychology of Mathematics Education, Toronto, Canada. Retrieved from http://www. allacademic.com/meta/p117624_index.html_

Neuman, W. L. (2006). Social research methods: Qualitative and quantitative approaches. United States: Pearson.

Noraini Idris, Loh, S. C., Norjoharuddeen Mohd. Nor, Ahmad Zabidi Abdul Razak, \& Rahimi Md. Said. (2007). The professional preparation of Malaysian teachers in the implementation of teaching and learning of mathematics and science in English. Eurasia Journal of Mathematics, Science \& Technology Education, 3(2), 101-110.

Schon, D. A. (1987). Educating the reflective practitioner: Toward a new design for teaching and learning in the professions. San Francisco: Jossey-Bass.

Shimahara, N. K. (1998). The Japanese model of professional development: Teaching as craft. Teaching \& Teacher Education, 14(5), 451-462.

Shulman, L. S. (1986). Those who understand: Knowledge growth in teaching. Educational Researcher, 15(2), 4-14.

Silverman, D. (2005). Interpreting qualitative data: Methods for analysing talk, text and interaction. London: Sage Publications.

Stigler, J. W., \& Hiebert, J. (1999). The teaching gap: Best ideas from the world's teachers for improving education in the classroom. NewYork: The Free Press.

UNESCO. (1987). In-service training and tomorrow's primary education. Bangkok: UNESCO Regional office for Education in Asia and the Pacific.

Vygotsky, L. S. (1978). Mind in society. Cambridge: Harvard University Press.

Wang-Iverson, P. (2002). Lesson study's effect on affect. Paper presented at the American Educational Research Association (AERA) annual meeting, New Orleans.

Yin, R. K. (1994). Case study research: Design and methods. Thousand Oaks: Sage Publications. 